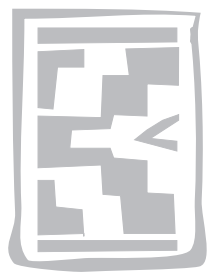

\title{
Gross pathological findings in sows of different parity, culled due to recurring swine urogenital disease (SUGD) in Kenya
}

\author{
M.H. BOMA and G. BILKEI* \\ Veterinary Consulting, Bahnhofstrasse 42, CH - 8600 Dübendorf, Switzerland
}

\begin{abstract}
BOMA, M.H. \& BILKEI, G. 2006. Gross pathological findings in sows of different parity, culled due to recurring swine urogenital disease (SUGD) in Kenya. Onderstepoort Journal of Veterinary Research, 73:139-142

In a large Kenyan production unit the urogenital organs and mammary glands of 771 sows, culled due to recurring swine urogenital disease (SUGD) were subjected to necropsy Necropsy findings were analysed separately according to parity group of the sows [parities $2(n=252) ; 3-5(n=250)$; and $>5$ $(n=269)]$. Sows of higher parities had more pathological changes in their ovaries, uteri, vaginas, cervices, urinary bladders, kidneys and mammary glands compared to parity 2 sows $(P<0.05$ and $P<0.01$, respectively). Parity 2 sows had more ovarian degeneration, mucosal hyperaemia, congestion in the bladder, and acute purulent exudative mastitis than parity $>5$ sows $(P<0.05$ and $P<0.01$, respectively).

Keywords: Mammary glands, parity, sow, urogenital organs
\end{abstract}

\section{INTRODUCTION}

Swine urogenital diseases (SUGD) are often found in combination with mastitis metritis agalactia syndrome (MMA) (Waller, Bilkei \& Cameron 2002) and may contribute to inferior litter size (Sanders \& Bilkei 2004), inadequate lactation performance, lower farrowing rate (Thacker \& Bilkei 2005), and abortion and sow mortality (D'Allaire \& Drolet 1992). In a retrospective study (Bilkei, Bölcskei \& Goos 1995), 101 sows that had been culled for reproductive failure, revealed gross pathological changes in the urinary bladder, urethra and mammary glands in all cases; $50 \%$ also had uterine changes. In similar work (Bilkei \& Goos 1994), $73 \%$ of sows culled for reproductive failure were found to have inflammatory changes

* Author to whom correspondence is to be directed. E-mail: bilkei.consulting@gmx.net

Accepted for publication 30 March 2006-Editor involving both the urogenital tract and the mammary glands.

The present retrospective study was performed in order to prove a relationship between pathological changes in different parts of the urogenital organs and mammary glands in a hot African climate in sows of different parity culled due to recurring SUGD.

\section{MATERIAL AND METHODS}

The trial was performed in a large Kenyan indoor production unit (2239 sows) from August 2004 to August 2005.

All culled sows with recurring SUGD $(n=771)$ in their history were examined at necropsy. These sows were assigned to parity groups $2(n=252), 3-5$ ( $n=$ $250)$ and $>5(n=269)$, and necropsy findings associated with these groups were analysed separately. The pathological changes in ovaries, uteri, vaginas, 
Pathological findings in sows, culled due to recurring swine urogenital disease in Kenya

cervices, urinary bladders, renal pelves, and mammary glands were evaluated.

For the purpose of this study, the pathological examinations were performed according to the following criteria:

\section{Ovaries}

- Adhesions between oviduct and ovaries

- Ovarial cysts

- Multiple tertiary follicles and regressed corpora lutea

- Ovarian degeneration (small firm ovaries)

Uteri

- Distended uterus with purulent or necrotic debris

- Thickening and ulceration of the uterine wall

- Adhesive and inflammatory changes on serosa of uterus

\section{Vaginas and cervices}

- Ulceras in the vagina or cervix

- Fibrinopurulent exudate on the wall of the vagina

Bladders and renal pelves

- Cystitis

- Ulcers or fibrinopurulent exudate in the bladder

- Mucosal hyperaemia and congestion of the bladder

- Pyelonephritis, and pathological enlargement and widening of the ureterovesical junctions

\section{Mammary glands}

- Granulomatous mastitis

- Acute purulent exudative mastitis

- Chronic purulent exudative mastitis

- Mammary abscessation

- Mammary cysts

- Irregular scattered fibrous foci of mastitis

\section{RESULTS}

Parity 2 sows had more ovarian degeneration than sows of higher parities, in which there were more adhesions between oviduct and ovaries, ovarial cysts, multiple tertiary follicles and regressed corpora lutea $(P<0.05$ and $P<0.01$, respectively). Sows of higher parities had more pathological changes in their uteri, vaginas, and cervices when compared to those sows of parity $2(P<0.05$ and $P<0.01$, respectively). With the exception of mucosal hyperaemia, congestion of the bladder mucosa, and acute purulent mastitis, parity $>5$ sows had more pathological changes in the urinary bladder, renal pelves and mammary glands when compared to parity 2 sows $(P<0.05$ and $P<0.01$, respectively).

\section{DISCUSSION}

Consistent with the literature (Bilkei, Bölcskei, Clavadetscher, Goos, Hoffmann, Bilkei \& Szenci 1994; Dial, Marsh, Polson \& Vaillancourt 1992; Dee 1992; Waller et al. 2002; Sanders \& Bilkei 2004), in the present study, higher parity sows suffered more gross pathological urogenital and mammary gland changes than their younger counterparts.

Postparturient urogenital diseases significantly influence herd fertility and cause high economic losses (Almond \& Richards 1986; Waller et al. 2002). Many recent publications have focused on reasons for culling or cause of sow mortality due to SUGD or agerelated occurrence of SUGD (Bilkei et al. 1994, 1995; Dial et al. 1992; Dee 1992; Sanders \& Bilkei 2004).

The present study indicates, that as a sow gets older, pathological changes in one part of the urogenital organs will be followed by pathological changes in other parts of the urogenital tract and mammary glands. Parity at culling markedly influences the economic well-being of a pig breeding unit (D'Allaire \& Drolet 1992; Almond \& Richards 1986). It has also been suggested that sows, which repeatedly suffer postparturient SUGD, should be culled for economic reasons before a decline in production takes place (Bilkei et al. 1995; Bilkei \& Goos 1994). Biksi, Takacs, Vetesi, Fodor, Szenci \& Fenyö (2002) examined the urogenital organs of 499 sows and found that animals suffering from "urocystitis" were 3.5 times more likely to have endometritis than animals without "urocystitis".

The breakdown of uterine tissue provides a medium that favours the growth of a variety of opportunistic microorganisms originating from the urinary bladder and/or vestibulum vaginae (Dial et al. 1992; Sanders \& Bilkei 2004). Retention of remnants of the placenta may predispose sows to mild metritis and endometritis (Biksi et al. 2002). In addition, the reproductive tract of sows is susceptible to infection after farrowing because of the periparturient increase in the number of both apathogenic microflora and facultative pathogens in the caudal vagina and urinary bladder (Bilkei et al. 1994). While most bacteria are eliminated within 12-30 $\mathrm{h}$ after delivery, facultative pathogens may overgrow non-pathogenic microflora and establish mildly invasive endometritis (Bilkei et al. 1994). Biksi et al. (2002) stated that the sensitivity of macroscopic examination methods was not higher than $18.1 \%$ in cases of endometritis and $47.9 \%$ in cases of "urocystitis", while the sensitivity of bacteriology for the diagnosis of the same conditions was only $31.8 \%$ and $63.0 \%$, respectively. Similar to the present findings, 
TABLE 1 Gross pathological findings in urogenital organs and mammary glands in sows of different parity, culled due to urogenital infections in their previous history (number and percentage of cases in a parity group

\begin{tabular}{|c|c|c|c|}
\hline Pathology & $\begin{array}{l}\text { Parity } 2 \\
(n=252)\end{array}$ & $\begin{array}{l}\text { Parity 3-5 } \\
(n=250)\end{array}$ & $\begin{array}{l}\text { Parity > 5 } \\
(n=269)\end{array}$ \\
\hline $\begin{array}{l}\text { Adhesions between oviduct and ovaries } \\
\text { Ovarial cysts } \\
\text { Multiple tertiary follicles and regressed corpora lutea } \\
\text { Ovarian degeneration (small firm ovaries) } \\
\text { Distended uterus with purulent or necrotic debris } \\
\text { Thickening and ulceration of the uterus wall } \\
\text { Adhesive or inflammatory changes on uterine serosa } \\
\text { Ulcerations in the vagina or cervix } \\
\text { Fibrinopurulent exudate on the vaginal mucosa } \\
\text { Cystitis } \\
\text { Ulcerations or fibrinopurulent exudate in the bladder } \\
\text { Mucosal hyperaemia and congestion in the bladder } \\
\text { Pyelonephritis and pathological enlargement and widening of } \\
\text { ureterovesical junction } \\
\text { Granulomatous mastitis } \\
\text { Acute purulent exudative mastitis } \\
\text { Chronic purulent exudative mastitis } \\
\text { Mammary abscessation } \\
\text { Mammary cysts } \\
\text { Irregular scattered fibrous foci of mastitis }\end{array}$ & $\begin{array}{l}81 / 32.1 \mathrm{a} \\
72 / 28.6 \mathrm{a} \\
22 / 8.7 \mathrm{a} \\
202 / 80.2 \mathrm{c} \\
2 / 0.8 \mathrm{a} \\
2 / 0.8 \mathrm{a} \\
1 / 0.4 \mathrm{a} \\
69 / 27.4 \mathrm{a} \\
4 / 1.6 \mathrm{a} \\
4 / 1.6 \mathrm{a} \\
2 / 0.8 \mathrm{a} \\
204 / 81.0 \mathrm{~b} \\
2 / 0.8 \mathrm{a} \\
2 / 0.8 \mathrm{a} \\
69 / 27.4 \mathrm{~b} \\
229 / 90.9 \mathrm{~b} \\
2 / 0.8 \mathrm{a} \\
4 / 1.6 \mathrm{a} \\
2 / 0.8 \mathrm{a}\end{array}$ & $\begin{array}{l}89 / 35.6 \mathrm{a} \\
79 / 31.6 \mathrm{a} \\
99 / 39.6 \mathrm{~b} \\
28 / 11.2 \mathrm{a} \\
8 / 3.2 \mathrm{~b} \\
18 / 7.2 \mathrm{~b} \\
7 / 2.8 \mathrm{~b} \\
70 / 28.8 \mathrm{a} \\
67 / 26.8 \mathrm{~b} \\
69 / 27.6 \mathrm{~b} \\
94 / 37.6 \mathrm{~b} \\
103 / 41.2 \mathrm{~b} \\
73 / 29.2 \mathrm{~b} \\
111 / 44.4 \mathrm{c} \\
21 / 8.4 \mathrm{a} \\
76 / 30.4 \mathrm{a} \\
55 / 22.0 \mathrm{~b} \\
110 / 44.0 \mathrm{~b} \\
224 / 89.6 \mathrm{c}\end{array}$ & $\begin{array}{l}229 / 85.1 b \\
200 / 74.3 b \\
213 / 79.2 c \\
42 / 15.6 a \\
212 / 78.8 c \\
37 / 13.8 b \\
99 / 36.8 c \\
203 / 75.5 b \\
209 / 77.7 c \\
302 / 83.9 c \\
204 / 75.8 c \\
34 / 12.6 a \\
174 / 64.7 c \\
217 / 80.7 c \\
27 / 10.0 a \\
206 / 76.6 b \\
201 / 74.7 c \\
202 / 75.1 c \\
266 / 100.0 c\end{array}$ \\
\hline
\end{tabular}

$\mathrm{a}, \mathrm{b} ; \mathrm{b}, \mathrm{c}$ in a row, the difference is significant $(P<0.05)$

a, $\mathrm{C} \quad$ in a row, the difference is significant $(P<0.01)$

Biksi et al. (2002) found that a large proportion of animals that they had examined did not show inflammatory lesions.

The recovery from postpartal SUGD is influenced by many factors, including the hormonal status of the sow, and local immunity, and possibly by reduced leukocyte activity and delayed immune response of the postpartum uterus (Bilkei \& Goos 1994). Stress, outdoor production, and an unsatisfactory hygienic environment might trigger SUGD in the postparturient sow (Thacker \& Bilkei 2005).

The results of this study indicate that sows having suffering from recurring postparturient urogenital diseases should be culled for economic reasons before the manifestation of low reproductive production level.

\section{ACKNOWLEDGEMENTS}

We thank Miss Verena Doviane, Bilkei Consulting, Dübendorf, Switzerland for her technical assistance.

\section{REFERENCES}

ALMOND, G.W. \& RICHARDS, R.G. 1986. Evaluating porcine reproductive failure by use of slaughter checks. Compendium on Continuous Education of Practitioner Veterinarians, 14: 542-546.
BIKSI, I., TAKACS, N., VETESI, F., FODOR, L., SZENCI, O. \& FENYÖ, E. 2002. Association between endometritis and urocystitis in culled sows. Acta Veterinaria Hungarica, 50:413423.

BILKEI, G. \& GOOS, T. 1994. Evaluation of the occurrence of SUGD (Swine Urogenital Disease) in large pig production units. Proceedings of $13^{\text {th }}$ International Pig Veterinary Society Congress, Bangkok, Thailand. 5-11 July 1994:472.

BILKEI, G., BÖLCSKEI, A., CLAVADETSCHER, E., GOOS, T., HOFFMANN, C., BILKEI, H. \& SZENCI, O. 1994. Bericht über den peripartalen Krankheitskomplex der Muttersau in der industriellen Schweinezucht. 3te Mitteilung: Schlachtbefunde von Altsauen mit der Anamnese von peripartalen Erkrankungen. Berliner und Münchener Tierärztliche Wochenschrift, 107:405-408.

BILKEI, G., BÖLCSKEI, A. \& GOOS, T. 1995. Pathogene Befunde aus dem Urogenitaltrakt ausgemerzter Muttersauen aus einem Grossbestand. Tierärztliche Praxis, 23:37-41.

D'ALLAIRE, S. \& DROLET, R. 1992. Culling and mortality in breeding animals, in Diseases of swine, $7^{\text {th }}$ ed., edited by A.D. Leman, B.E. Straw, W.L. Mengeling, S.D. D'Allaire \& D.J. Taylor. London: Wolfe Publications.

DEE, S.A. 1992. Porcine urogenital disease, in Food animal practice, swine reproduction Veterinary Clinics of North America, 8:641-660.

DIAL, G.D., MARSH, W.E., POLSON, D.D. \& VAILLANCOURT, J.P. 1992. Reproductive Failure: Differential Diagnosis, in Diseases of swine, $7^{\text {th }}$ ed., edited by A.D. Leman, B.E. Straw, W.L. Mengeling, S.D. D'Allaire \& D.J. Taylor. London: Wolfe Publications.

SANDERS, L.M.G. \& BILKEI, G. 2004. Urogenital diseases and their effect on reproductive performance in high-parity sows. Tijdschrift voor Diergeneeskunde, 129:108-112. 
Pathological findings in sows, culled due to recurring swine urogenital disease in Kenya

THACKER, M.H. \& BILKEI, G. 2005. The effect of urogenital diseases on subsequent reproductive performance of indoor and outdoor sows. The Veterinary Record, 156:683-684.
WALLER, C.M., BILKEI, G. \& CAMERON, R.D.A. 2002. Effect of periparturient disease and/or reproductive failure accompanied by excessive vulval discharge and weaning to mating interval on sows' reproductive performance. Australian Veterinary Journal, 80:545-549. 